\title{
Didactical Design Realistic Mathematics Education Based on Green Mathematics in Direct \& Indirect Proportions Concept at Junior High School
}

\author{
Idvan Aprizal Bintara*, Tatang Herman, Aan Hasanah \\ Mathematics Education Department, Faculty of Mathematics and Science Education, Universitas Pendidikan Indonesia, \\ Jl. Dr. Setiabudi No. 229 Bandung, Jawa Barat 40154. Telp. 022-2013163, Fax. 022-2013651. \\ Email*: idvanaprizalb@upi.edu
}

\begin{abstract}
This research is motivated by students' learning obstacles in direct \& indirect proportions concept through literature studies and preliminary studies conducted by a researcher. Furthermore, the environmental care attitude of students is low. The purpose of the research is to create the alternative didactical design; a didactical design Realistic Mathematics Education based on Green Mathematics consisting of four lesson designs arranged due to learning obstacle in direct \& indirect proportions concept, as well as relevant learning theory. Four lessons were implemented for 40 seventh grade students in Lembang who have not learned yet about the concept. The research method used in this study is qualitative research as Didactical Design Research. There are three stages in this study; the first stage is prospective analysis or didactic situation analysis producing hypothetical didactic design, the second stage is metapedadidactic analysis as implementation of hypothetical didactic design, and the third stage is retrospective analysis that produces empirical didactic design. The result shows that hypothetical didactic design can minimize the students' learning obstacles in direct \& indirect proportions concept; almost all student showed environmental care attitude is well; and almost all student showed positive attitude towards mathematics learning using hypothetical didactic design. Based on the results of the research, developed didactical design that can be applies as one of the alternative for teaching materials in direct $\&$ indirect proportions learning concept at schools that have the same characteristics.
\end{abstract}

Key words: Didactical Design, Direct \& Indirect Proportions, Green Mathematics, Learning Obstacle, Realistic Mathematics Education

Abbreviations: DDR, Didactical Design Research; RME, Realistic Mathematics Education.

\section{INTRODUCTION}

Mathematics is one of the subjects that has a big role in the development of human thought patterns. Suryadi (2010) states that mathematics learning is related to the development of students' potential in thought thinking. Through mathematics, students are not only expected to be able to perform arithmetic operations, but also become conscientious, careful, and wise people in making decisions in an effort to solve everyday problems.

The role of mathematics is of great concern to everyone, including the Indonesian government. This is proven by the formulation of the objectives of mathematics learning in PERMENDIKBUD Number 58 of 2014 concerning 2013 Curriculum of SMP / MTs. In general, the purpose of learning mathematics is not just to memorize and use formulas, but rather to understand mathematical concepts through meaningful and effective learning to be applied in solving everyday problems. This is in accordance to Jerome Bruner's statement (Suherman, 2001) that learning will be effective if it uses the concept structure so that the relationship between one concept and the other concepts as well as the relationship between the prerequisite concepts and the successor concept. Moreover, mathematics is a discipline that is rich in concepts. The concepts in mathematics have a high enough relation, namely one concept can support the other concepts. So that the ability to learn new material requires a complete understanding of one or more concepts that have been learned before. One concept that is quite important in learning mathematics is the concept of proportion. This proportion concept will be found and used by students in learning other mathematical material to solve real problems in everyday life (Ojose, 2015; Valverde \& Castro, 2012).

The facts found in the field are that there are still some students who experience obstacles in learning mathematics (learning obstacle). In accordance with the results of several studies that have been carried out previously which showed the learning obstacle (ontogenic obstacle, didactical obstacle, and epistemological obstacle) of junior high school students on the concept of proportion. Students do not understand the basic concepts of proportion and cannot distinguish problems related to direct and indirect proportions (Arican, 2016; Cortina, Visnovska \& Zuniga, 2014; Kharimah, 2013; Stacey \& MacGregor, 1999).

Based on some of the above research, it can be said that the ability of students to understand the concept of proportion is not optimal, so we need a learning plan (didactical design) to minimize or anticipate the emergence of learning obstacles. Sodikin, et al. (2015) states that teaching materials compiled based on 
consideration of learning obstacles can minimize the difficulties experienced by students.

According to Cashin (Fitriyani, 2011), the first variable that causes inefficient teaching is students who are passive because they do not like or are not interested in the teaching material provided. The way to overcome this is to make teaching materials that are innovative, creative, interesting, able to motivate and provide inspiration for students by paying more attention to the context used to fit the student's experience or relating to the state of the student's environment (contextual). This is in accordance with the Realistic Mathematics Education (RME) model where learning begins with concrete problems or can be imagined by students. One context that can be given to students is related to the environment, so that the design of teaching materials presented is more interesting and closer to students' daily lives. The reason for the importance of making a didactical design based on the environment is to apply and enhance the values of students' environmental care attitudes, because based on Rahayu's (2015) research findings that there are several dimensions of problems such as the low awareness of students to throw trash in their place, the amount of plastic waste, flower pots which changes the function of containing garbage, etc. which makes the environment not maintained.

Thus, the purpose of this study was to create an alternative didactical design on the concept of direct and indirect proportions of junior high school students, namely the didactical design of Realistic Mathematics Education based on Green Mathematics which was prepared based on students' learning obstacles and relevant learning theories.

\section{MATERIALS AND METHODS}

\section{Study Area}

This research is a qualitative research in the form of a Didactical Design Research. Data collection techniques used in this study use triangulation techniques to meet data credibility. Participants in this study were several students in one of the junior high schools in Lembang, which were divided into two groups. The first group to take the initial learning obstacle test, students of class VIII-A. While the second group who took the final learning obstacle test and who followed the learning used a hypothetical didactic design, namely students of class VII-F. The reason for choosing grades VIII-A and VII-F is because the math teacher is the same. Then, the selected schools are schools that are of medium quality. In addition, the selected school is still not free of plastic waste and students' environmental care attitudes are still low.

The main instrument in this research process is the researcher itself. However, there are supporting instruments for collecting data, such as the learning obstacle test instrument in the form of reasonable multiple-choice questions to find out the obstacles of students in the concept of direct and indirect proportions, as well as non-test instruments in the form of questionnaires and daily journals to find out students' attitudes toward didactical designs that have been implemented and environmental care attitude of student.

\section{Procedures}

According to Suryadi (2013), didactical design research consists of 3 stages, namely: the study begins with the prospective analysis stage (didactic situation analysis before learning takes place); then, the metapedadidactic analysis stage (didactic situation analysis that develops in the classroom); finally, the retrospective analysis stage (analysis that connects prospective and metapedadidactic analysis).

Table 1. Research Stages.

\begin{tabular}{ll}
\hline Stages & Description \\
\hline Prospective & Literature Study \\
analysis stages & Learning Obstacle Identification \\
& $\begin{array}{l}\text { Interviews with several students and } \\
\text { mathematics teachers } \\
\text { Making hypothetical learning trajectory } \\
\text { and didactical design }\end{array}$ \\
Metapedadidactic & $\begin{array}{l}\text { Implementation of a hypothetical didactic } \\
\text { design }\end{array}$ \\
Retrospective & Observing student responses as they arise \\
analysis stage & Distributing the questionnaire \\
& Identify learning obstacles \\
& Making empirical didactic designs \\
\hline
\end{tabular}

\section{Data analysis}

Data were analyzed descriptively/narratively. Data analysis in this research took place from before the writer entered the field until the implementation took place. Before entering the field, an analysis of the results of the preliminary study will be used to determine the focus of the study. Whereas while in the field, the analysis was carried out when the data collection took place using the Miles and Huberman model (Sugiyono, 2015), namely:

1. Data Reduction

The data obtained from the field are quite a lot, such as from the results of the learning obstacle test and the results of the implementation of a hypothetical didactic design, so data reduction is needed to get a clearer picture and make it easier for researchers to conduct further data collection.

2. Data Presentation

Presentation of the data is done in the form of a brief narrative description, and to make it easier to see the results of several studies presented in tabular form, relationships between categories, and so on. 
3. Withdrawal of Conclusions and Verification The initial conclusions put forward are temporary and will change if no strong evidence is found to support the data collection stage. However, if the initial conclusions put forward are based on strong evidence, then the conclusions are credible conclusions.

In addition, in processing the questionnaire in this study, researchers used a Likert scale. According to Sugiyono (2015), the Likert scale can be used to measure the attitudes, opinions, and perceptions of a person or group about social phenomena.

\section{RESULTS AND DISCUSSION}

\section{Prospective Analysis Stage}

The prospective analysis stage begins with a preliminary study. A preliminary study was conducted to find out the students' learning obstacle in one of the junior high schools in Lembang. The preliminary study conducted in this study was in the form of an learning obstacle identification test on the concept of direct and indirect proportions. The researcher identified learning obstacle in several ways, namely through the learning obstacle identification test, interviews of several students and mathematics teachers, and the learning resources used by students. The learning obstacles identified in this study are as follows:

Table 2. The Result of Students' Learning Obstacle Identification.

\begin{tabular}{|c|c|c|c|}
\hline & $\begin{array}{l}\text { Analysis of the Learning } \\
\text { Obstacle Identification Test }\end{array}$ & $\begin{array}{l}\text { Analysis of Student and } \\
\text { Teacher Interview Results }\end{array}$ & $\begin{array}{l}\text { Analysis of Learning } \\
\text { Resources used }\end{array}$ \\
\hline \multirow[b]{2}{*}{$\begin{array}{l}\text { Ontogenical obstacle (due to students' } \\
\text { thinking abilities that are not ready to } \\
\text { accept new knowledge) }\end{array}$} & $\sqrt{ }$ & $\sqrt{ }$ & $\sqrt{ }$ \\
\hline & \multicolumn{3}{|c|}{$\begin{array}{l}\text { Students have difficulty recognizing direct proportion; students do not understand the } \\
\text { concept of ratio; and students have difficulty in conecting proportion problems with } \\
\text { multiplicative situations. }\end{array}$} \\
\hline \multirow[b]{2}{*}{$\begin{array}{l}\text { Epistemological Obstacle (due to the } \\
\text { limitations of the students in certain } \\
\text { contexts) }\end{array}$} & $\sqrt{ }$ & $\sqrt{ }$ & $\sqrt{ }$ \\
\hline & \multicolumn{3}{|c|}{$\begin{array}{l}\text { Students cannot solve the problem of indirect proportion in the context using graphs; } \\
\text { students cannot solve problems of direct proportion in the context associated with algebra; } \\
\text { and students cannot solve the problem of indirect proportion with the context of unusual } \\
\text { questions. }\end{array}$} \\
\hline \multirow{2}{*}{$\begin{array}{l}\text { Didactical Obstacle (due to a mismatch } \\
\text { in teacher teaching) }\end{array}$} & $\sqrt{ }$ & $\sqrt{ }$ & $\sqrt{ }$ \\
\hline & \multicolumn{3}{|c|}{$\begin{array}{l}\text { Students are only able to solve problems using procedures or formulas that are memorized } \\
\text { when the teacher gives them in class. }\end{array}$} \\
\hline
\end{tabular}

The results of the identified learning obstacle analysis will be used as a guide in predicting various student responses that occur during the learning process and developing didactic anticipation to achieve learning goals. Therefore, the researcher obtained a picture to compile a learning trajectory to produce a hypothetical didactic design. Learning trajectory compiled in this study are:

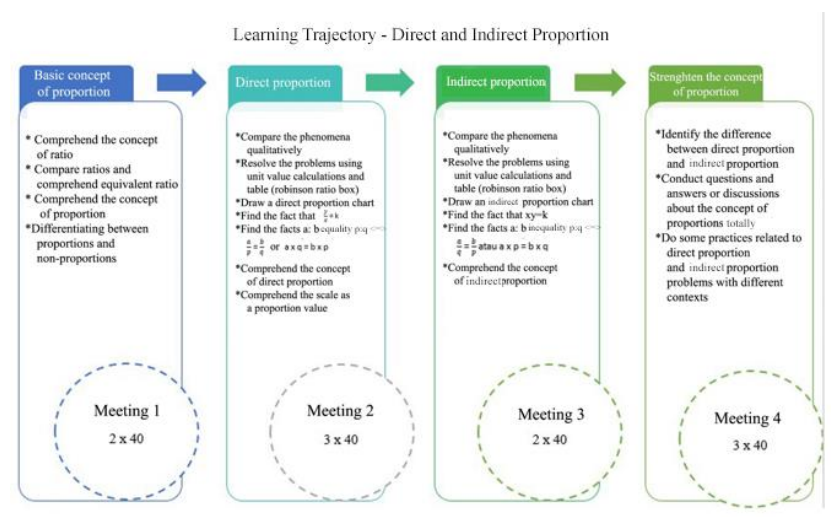

Figure 1. Learning Trajectory.
Learning trajectory is arranged based on the results of learning obstacles in order to achieve the optimal learning. Hypothetical didactic designs based on realistic mathematics education so that students more easily understand concepts and to be linear with green mathematics, because learning is associated with everyday life. This is supported by the results of Evayanti's research (2017) that didactical designs using realistic mathematics education can minimize students' learning obstacle. Therefore, the preparation of this hypothetical didactic design pays attention to the six principles of realistic mathematics education in accordance with the opinion of Van Den Heuvel (2014), that is activity principle, reality principle, level principle, intertwinement principle, interactivity principle, and guidance principle. In addition, making didactical design also refers to relevant learning theories.

The hypothetical didactic design that was compiled consisted of four lesson designs with different life contexts (environmental problems). Each lesson design includes several didactic situations that are arranged with regard to student responses and didactic anticipation. The details of the hypothetical didactic design arranged are as follows: 
Table 3. Details of Hypothetical Didactic Design.

\begin{tabular}{|c|c|c|}
\hline Time Allocation & Theme & Lesson Design Content \\
\hline $\begin{array}{l}\text { Lesson Design I } \\
(2 \mathrm{x} 40 \text { minutes })\end{array}$ & $\begin{array}{l}\text { Basic Concepts of Proportion } \\
\text { (Plastic Trash Problems) }\end{array}$ & \\
\hline $\begin{array}{l}\text { Lesson Design II } \\
(3 \times 40 \text { minutes })\end{array}$ & $\begin{array}{l}\text { Direct Proportion } \\
\text { (Polluted River Problems) }\end{array}$ & $\begin{array}{ll}\text { 1. Opening } \\
\text { 2. Discussion } \\
\text { 3. Let's explore the information }\end{array}$ \\
\hline $\begin{array}{l}\text { Lesson Design III } \\
(2 \times 40 \text { minutes })\end{array}$ & $\begin{array}{l}\text { Indirect Proportion } \\
\text { (Drought Problems) }\end{array}$ & $\begin{array}{ll}\text { 4. } & \text { Activity } 1 / 2 \\
\text { 5. Let's have a practice } \\
\text { 6. Closing }\end{array}$ \\
\hline $\begin{array}{l}\text { Lesson Design IV } \\
(3 \times 40 \text { minutes })\end{array}$ & $\begin{array}{l}\text { Review the Proportion Concept } \\
\text { (Other problems of Natural Environment) }\end{array}$ & \\
\hline
\end{tabular}

\section{Metapedadidactic Analysis Stage}

Furthermore, in the metapedadidactic analysis stage. At this stage, a hypothetical didactic design that was compiled was then implemented by the researcher (acting as a teacher) to approximately 40 VII-F grade students in one of the junior high schools in Lembang. The number of meetings was divided into four meetings, according to the researchers' initial plan to make four lesson designs. After the implementation of a hypothetical didactic design, it appeared that some students' responses were out of prediction, so an empirical didactic design was drawn up which was the result of a revision of the hypothetical didactic design.

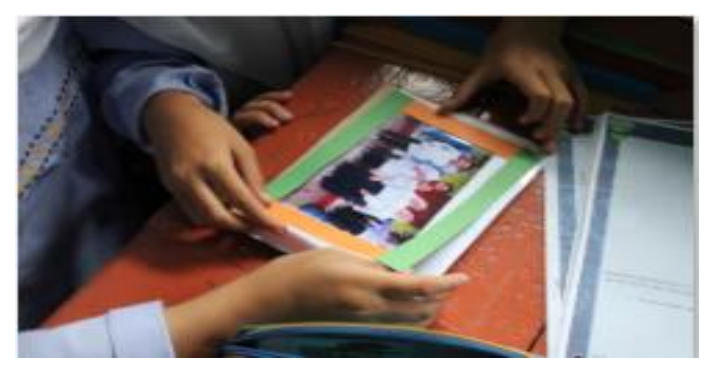

Figure 2. Students make a frame made of used goods using the

Table 4. Results of a Hypothetical Didactic Design Revision.

\begin{tabular}{|c|c|c|}
\hline Activity & Before revision & After revision \\
\hline \multicolumn{3}{|c|}{ Lesson Design I } \\
\hline $\begin{array}{l}\text { Apperception } \\
\text { Situation }\end{array}$ & No apperception Situation & Adding apperception situation about fraction and integer operations \\
\hline $\begin{array}{l}\text { Instructions in } \\
\text { writing Ratios }\end{array}$ & $\begin{array}{l}\text { Simplification is done on the } \\
\text { forms } a \text { : } b\end{array}$ & Simplification is done on the form of fractions \\
\hline \multicolumn{3}{|c|}{ Lesson Design II } \\
\hline $\begin{array}{l}\text { Apperception } \\
\text { Situation }\end{array}$ & No apperception Situation & $\begin{array}{l}\text { Adding apperception situation about the concept of ratio, proportion, } \\
\text { and rate }\end{array}$ \\
\hline $\begin{array}{l}\text { Questions in the } \\
\text { "Let's explore the } \\
\text { Information" section }\end{array}$ & $\begin{array}{l}\text { What do you know about the } \\
\text { above situations? }\end{array}$ & What pattern did you find from the situation above? \\
\hline
\end{tabular}

Figure 3. One of the students' response of problem solving in the lesson concept of proportion. design.

\section{Retrospective Analysis Stage}

According to the students' responses beyond predictions appear on the implementation of a hypothetical didactic design, so that a revised didactical design was made. Some of the revised hypothetical didactic design sections are as follows: 


\begin{tabular}{|c|c|c|}
\hline $\begin{array}{l}\text { Didactic } \\
\text { Anticipation in } \\
\text { Activity } 1\end{array}$ & $\begin{array}{l}\text { No didactic anticipation to } \\
\text { overcome students who only use } \\
\text { one method }\end{array}$ & $\begin{array}{l}\text { Adding didactic anticipation, ie the teacher asks students to } \\
\text { memorize tables / graphs. }\end{array}$ \\
\hline $\begin{array}{l}\text { Instruction in } \\
\text { activity } 2\end{array}$ & $\begin{array}{l}\text { No instruction to draw a } \\
\text { Cartesian diagram. }\end{array}$ & $\begin{array}{l}\text { Adding instructions to draw a Cartesian diagram first, and there is a } \\
\text { revision of the questions. }\end{array}$ \\
\hline \multicolumn{3}{|c|}{ Lesson Design III } \\
\hline $\begin{array}{l}\text { Apperception } \\
\text { Situation }\end{array}$ & No apperception Situation & $\begin{array}{l}\text { Add apperception situations about the characteristics of direct } \\
\text { proportion. }\end{array}$ \\
\hline $\begin{array}{l}\text { Questions in the } \\
\text { "Let's explore the } \\
\text { Information" section }\end{array}$ & $\begin{array}{l}\text { What do you know about the } \\
\text { above situations? }\end{array}$ & What pattern did you find from the situation above? \\
\hline $\begin{array}{l}\text { Didactic } \\
\text { Anticipation in } \\
\text { Activity } 1\end{array}$ & $\begin{array}{l}\text { No didactic anticipation } \\
\text { overcoming students drawing } \\
\text { straight graphs. }\end{array}$ & $\begin{array}{l}\text { Adding didactic anticipation, ie the teacher asks students to pay } \\
\text { attention to the distances of points } \mathrm{x} \text { and } \mathrm{y} \text {. }\end{array}$ \\
\hline $\begin{array}{l}\text { Question in activity } \\
1\end{array}$ & No proportion forms. & Added the proportion form in the cross-multiplication explanation. \\
\hline \multicolumn{3}{|c|}{ Lesson Design VI } \\
\hline $\begin{array}{l}\text { Apperception } \\
\text { Situation }\end{array}$ & No apperception Situation & $\begin{array}{l}\text { Add apperception situations about the characteristics of direct and } \\
\text { indirect proportions. }\end{array}$ \\
\hline
\end{tabular}

From the results of the didactical design revision above an empirical didactic design was arranged which was expected to be better in overcoming learning obstacles. Next, the researcher analysed all the data from the results of questionnaires, daily journals, and interviews conducted after the implementation of a hypothetical didactic design. The questionnaire conducted data analysis using a Likert scale. And the results obtained are the average attitude of students $82.9 \%$ (very good) towards learning using didactical realistic mathematics education design based on green mathematics on the concept of direct and indirect proportions (supported from the results of identifying the final learning obstacle better than learning obstacle early), and the average environmental care attitude of students $82.2 \%$ (very good) after the implementation of the hypothetical didactic design

\section{CONCLUSIONS}

Based on the results of research that has been done, it was concluded that students of class VIII-A in the school under study experienced several learning obstacles, so a hypothetical didactic design was composed of four lesson designs based on the six principles of RME and several relevant learning theories. Didactical design is based on green mathematics, meaning that didactical design is packaged with an environmental context in order to overcome the students' low environmental care attitudes. The hypothetical didactic design underwent revision because during the implementation there were some responses from students outside of predictions, so an empirical didactic design was arranged. Didactical design realistic mathematics education based on green mathematics on the concept of direct and indirect proportions can minimize students' learning obstacle in one of the junior high schools in Lembang. Also, students' attitudes toward this didactical design and environmental care attitude of students after the implementation of didactical designs to be more positive.

\section{ACKNOWLEDGEMENTS}

This research was supported by Mathematics Education Department, Universitas Pendidikan Indonesia. We thank our colleagues from one of junior high schools in Lembang, especially mathematics teacher for sharing their pearls of wisdom to us during the course of this research. We are also immensely grateful to all parties who have contributed for this research.

\section{REFERENCES}

Arican, M. 2016. Preservice Middle and High School Mathematics Teachers' Strategies when Solving Proportion Problems. International Journal of Science and Mathematics Education. 16(2), 315-335.

Cortina, J. L., Visnovska, J. \& Zuniga, C. 2014. Unit Fractions in the Context of Proportionality: Supporting Students' Reasoning about the Inverse Order Relationship. Mathematics Education Research Journal, 26(1), 79-99. 
Evayanti. M. 2017. Desain Didaktis Konsep Garis dan Sudut Berdasarkan Realistic Mathematics Education (RME) pada Pembelajaran Matematika Sekolah Menengah Pertama (SMP). [Tesis]. Universitas Pendidikan Indonesia, Bandung. [Indonesia]

Fitriyani. 2011. Desain Didaktis Konsep Luas Daerah Trapesium pada Pembelajaran Matematika. [Skripsi]. Universitas Pendidikan Indonesia, Bandung. [Indonesia]

Kharimah, U. 2013. Penggunaan Media Peta untuk Memahamkan Materi Perbandingan melalui Pembelajaran Kooperatif Tipe Grup Investigasi pada Siswa Kelas VII-A SMP Negeri 2 Jetis Kabupaten Mojokerto. [Skripsi]. Universitas Negeri Malang, Malang. [Indonesia]

Ojose, B. 2015. Proportional Reasoning and Related Concepts: Analysis of Gaps and Understandings of Middle Grade Students. Universal Journal of Educational Research, 3(2), 104-112. DOI: 10.13189/ujer.2015.030206

Rahayu, R. P. 2015. Peningkatan Sikap Peduli Lingkungan Siswa Melalui Metode Tugas dalam Pembelajaran IPS (Penelitian Tindakan Kelas di SMP Negeri Tanjungsari Kelas VIII A). [Skripsi]. Universitas Pendidikan Indonesia, Bandung. [Indonesia]

Sodikin, dkk. 2015. Desain Didaktis Konsep Luas Daerah dan Volume Benda Putar dalam Pembelajaran Matematika SMA. In: Ibrahim, Suyono dkk. (eds) Pembelajaran dan Penilaian Sains sesuai tuntutan Kurikulum 2013; Prosiding Seminar Nasional Pendidikan Sains Tahun 2015. Universitas Negeri Surabaya, Surabaya, 24 January 2015. [Indonesia]
Stacey, K. \& MacGregor, M. 2000. Learning the Algebraic Method of Solving Problems. Journal of Mathematical Behavior, 18(2), 149-167. DOI: 10.1016/S07323123(99)00026-7

Sugiyono. 2015. Metode Penelitian Pendidikan (Pendekatan Kuantitatif, Kualitatif, dan R\&D). Alfabeta, Bandung.

Suherman, E. 2001. Strategi Pembelajaran Matematika Kontemporer. JICA-UPI, Bandung.

Suryadi, D. 2010. Teori, paradigma, prinsip dan pendekatan pembelajaran MIPA dalam konteks Indonesia. FPMIPA-UPI, Bandung.

2013. "Didactical Design Research (DDR) dalam Pengembangan Pembelajaran Matematika"; In: Sumarmo, Utari dkk. (eds) Peran Matematika dalam Mengembangkan Humanisme dan Karakter Peserta Didik (Menyongsong Kurikulum 2013); Prosiding Seminar Nasional Matematika dan Pendidikan Matematika. Universitas Pendidikan Indonesia, Bandung, 31 Agustus 2013. [Indonesia]

Valverde, G. \& Castro, E. 2012. Prospective Elementary School Teachers' Proportional Reasoning. PNA, 7(1), 1-19.

Van den Heuvel-Panhuizen, M., \& Drijvers, P. (2014). "Realistic Mathematics Education". In Encyclopedia of Mathematics education (hlm. 521-525). Springer, Dordrecht. 